\title{
Marine mammals used as bait for improvised fish aggregating devices in marine waters of Ecuador, eastern tropical Pacific
}

\author{
Cristina Castro ${ }^{1}$, Koen Van Waerebeek ${ }^{2}$, Diana Cárdenas ${ }^{1,3}$, Juan José Alava ${ }^{4,5, *}$ \\ ${ }^{1}$ Pacific Whale Foundation-Ecuador, Malecón Julio Izurieta, Puerto López, Manabí, Ecuador \\ ${ }^{2}$ Peruvian Centre for Cetacean Research - Centro Peruano de Estudios Cetológicos (CEPEC), Pucusana, Lima 20, Perú \\ ${ }^{3}$ Escuela Superior Politécnica del Litoral, ESPOL, Facultad de Ciencias de la Vida, Laboratorio para Investigaciones \\ Biomédicas, Campus Gustavo Galindo Km 30.5 Vía Perimetral, P.O. Box 09-01-5863, Guayaquil, Ecuador \\ ${ }^{4}$ Fundación Ecuatoriana para el Estudio de Mamíferos Marinos (FEMM), Guayaquil, Ecuador \\ ${ }^{5}$ Institute for the Oceans and Fisheries, University of British Columbia, 2202 Main Mall, Vancouver, BC V6T 1Z4, Canada
}

\begin{abstract}
Fish aggregating devices (FADs) are floating objects typically used to attract and capture pelagic fish in industrial tuna fisheries. This study documents 9 cases, involving 31 marine mammals, of incidentally captured, killed or otherwise retrieved cetaceans and pinnipeds which were used, or presumably used, as bait for improvised fish aggregation devices (IFAD) by artisanal fishers in coastal Ecuador. At least 3 species of small cetaceans were affected, including pantropical spotted dolphin Stenella attenuata, short-finned pilot whale Globicephala macrorhynchus, pygmy killer whale Feresa attenuata and an unidentified small delphinid, as well as South American sea lions Otaria byronia which were reportedly killed on purpose for this fishing practice. A sperm whale Physeter macrocephalus and a humpback whale Megaptera novaeangliae were presumably found floating at sea and opportunistically exploited as FADs. The South American sea lion represented $80.6 \%$ of marine mammals used as bait associated with FADs (25 sea lions out of 31 marine mammals), while the remaining 5 (possibly 6) cetacean species represented $19.4 \%$. This is the first report of baited FADs in Ecuador, the extent of which is still unknown. This fishing technique has not been documented in other nations along the west coast of South America, although baiting of gillnets with marine mammal parts is common in Peru. Without fisheries management and regulation, this illegal fishing practice could rapidly expand and lead to further direct kills and conservation problems for targeted marine mammal populations in the eastern tropical Pacific. A bottom-up fisheries policy in concert with community-based conservation to ban the use of marine mammals as FAD bait is recommended.
\end{abstract}

KEY WORDS: Cetacean $\cdot$ Pinniped $\cdot$ Sea turtles $\cdot$ Bycatch $\cdot$ Bait $\cdot$ Conservation $\cdot$ Fisheries management $\cdot$ South America $\cdot$ Pacific Ocean

\section{INTRODUCTION}

Fish aggregating devices (FADs) have traditionally been defined as structures floating at the surface of the ocean placed by fishers to increase fishing opportunities and specifically attract and capture both pelagic juvenile and adult fishes, such as tropical tuna including skipjack Katsuwonus pelamis, yellowfin Thunnus albacares and bigeye Thunnus obe-

*Corresponding author: j.alava@oceans.ubc.ca sus (Castro et al. 2002, Dempster \& Taquet 2004, Fonteneau et al. 2013, Hall \& Roman 2013, Moreno et al. 2016a). These devices are used widely in tropical and subtropical waters, mainly in countries from the Pacific, Atlantic and Indian Oceans which are part of the tuna Regional Fisheries Management Organizations (RFMOs), for recreational, artisanal, industrial and commercial fisheries with the aim to concentrate and capture pelagic fish (Dempster \& Taquet 2004,

(C) The authors 2020. Open Access under Creative Commons by Attribution Licence. Use, distribution and reproduction are unrestricted. Authors and original publication must be credited. 
Fonteneau et. al. 2013, Gershman et al. 2015, Murua et al. 2016). FADs can be constructed from artificial or natural materials by the fishers, or they simply consist of a floating object (Castro et al. 2002, Dempster \& Taquet 2004, Moreno et al. 2016a,b). The international tropical tuna purse-seine fisheries fleet maintains as many as 121000 drifting fish aggregating devices (dFADs) deployed by fishers in tropical oceans worldwide (Gershman et al. 2015, Moreno et al. 2016a). Other oceanic megafauna and epipelagic marine species such as sharks, sea turtles, and marine mammals also aggregate around FADs (Brehmer et al. 2012, Dagorn et al. 2013). The potential deleterious impacts of FADs due to high levels of bycatch and threats to the marine biodiversity of tropical pelagic ecosystems have been reviewed, highlighting the need for additional fisheries management actions and an improved management plan (Dagorn et al. 2013, Gershman et al. 2015). In particular, pelagic sharks, sea turtles, and other vulnerable marine species are entangled and killed in these FADs (Filmalter et al. 2013, Hall \& Roman 2013, Murua et al. 2016). Massive mortality of silky sharks Carcharhinus falciformis was reported on an annual basis in the Indian Ocean, where approximately 480000 to 960000 silky sharks are killed each year when caught in FADs (Filmalter et al. 2013).

Ecuador has the largest small-scale (artisanal) fleet in the southeastern Pacific (Alava et al. 2015, Martínez-Ortiz et al. 2015). According to the Secretariat of Fisheries Resources (Subsecretaría de Recursos Pesqueros [SRP]), there are 234 fishing communities, with a total of 19770 to 45000 artisanal boats and between 63970 and 87280 small-scale fishers registered as members of the current fishing population in Ecuador (Alava et al. 2015, 2019, Martínez-Ortiz et al. 2015). The small-scale fisheries on the Ecuadorian continental coast are represented by the artisanal coastal fishery, which uses small boats to fish in coastal areas, and the artisanal oceanic long-line fishery, which operates in the open sea with the support of a larger ship (Martínez-Ortiz et al. 2015). Both of them capture demersal and pelagic fish. The main fishing gear presently used include trammel or surface gillnets ('trasmallo') of $800 \mathrm{~m}$ long by $3 \mathrm{~m}$ high, the $3200 \mathrm{~m}$ long cachema longline ('espinel corvinero') with 800 hooks, the longline ('palangre') of 36 to $72 \mathrm{~m}$, and the purse-seine net ('red de cerco') up to $1300 \mathrm{~m}$ long and $30 \mathrm{~m}$ deep. In Ecuador, the smallscale fishing fleet uses mainly longlines and surface gillnets (mesh sizes: 7.5 to $13 \mathrm{~cm}$ ) to catch large pelagic fish species, including dorado or dolphin-fish Coryphaena hippurus, several tuna, billfish species and sharks (Alava et al. 2015, 2019, Martínez-Ortiz et al. 2015). However, while Ecuador is one of the top countries using drifting FADs in the tropical tuna purse seine industrial fleet (Gershman et al. 2015), the use of FADs has not been officially reported or implemented in small-scale or artisanal fisheries of Ecuador.

The lethal interaction of small cetaceans with fisheries is widely recognized as one of the biggest global conservation problems in recent decades (Northridge 1985, Reeves et al. 2003, Hucke-Gaete et al. 2004, Avila et al. 2018). In Ecuador, human activities have severe direct and indirect impacts on marine mammals, including deleterious fisheries interactions (Félix \& Samaniego 1994, Van Waerebeek et al. 1997, Alava et al. 2005a, 2012, 2019, Félix et al. 1997, Castro \& Rosero 2010, Jiménez et al. 2018), vessel collisions with cetaceans (Van Waerebeek et al. 2007, Félix \& Van Waerebeek 2005, Félix et al. 1997), and short-term impacts generated by whale-watching tourism (Scheidat et al. 2004). Additionally, skin diseases in marine mammals have been indirectly linked to contaminants (Castro et al. 2008, Jiménez \& Alava 2014, Van Bressem et al. 2015).

In Ecuador, 3 types of fishing gear have been associated with incidental captures of marine mammals: (1) surface gillnets set mainly for pelagic fishes, such as swordfish Xiphias gladius and billfishes (Istiophoridae); (2) longlines of different lengths also targeting pelagic fish; and (3) purse-seines targeting different tuna species such as yellowfin Thunnus albacares, bigeye, skipjack or barrilete but also dorado, croakers (Sciaenidae, Cynoscion spp.) (Alava et al. 2012, 2019, Castro \& Rosero 2010, Castro et al. 2018).

Prior studies have reported incidental capture rates of dolphins by Ecuadorian fishermen in coastal waters. Two catch rates with drift gillnets were estimated in the early 1990s, ranging from 0.04 dolphins per boat in Puerto Lopéz to 0.10 dolphins per boat for Santa Rosa (Félix \& Samaniego 1994). In the Gulf of Guayaquil, a daily catch rate for bottlenose dolphins Tursiops truncatus was estimated at 0.0064 dolphins $\mathrm{d}^{-1}$, or 0.019 bottlenose dolphins per trip, but the confidence intervals were very wide (Van Waerebeek et al. 1997). The highest incidental catch rate was obtained in August 2009 when 0.18 dolphins d ${ }^{-1}$ per equivalent trip was estimated (Castro \& Rosero 2010). However, there is no information about the use of marine mammals for fishing purposes in coastal Ecuador. At Puerto Bolívar (southern Ecuador), one fisherman admitted harpooning a bottlenose dolphin near Puná Island, for bait in the longline 
fishery, while fishers operating in the Gulf of Guayaquil indicated they either discarded bycaught dead dolphins at sea or, when possible, sold them for bait to Peruvian fishermen (Van Waerebeek et al. 1997).

While industrial tuna fishing operation deploying FADs at sea is known and managed by the InterAmerican Tropical Tuna Commission (IATTC) in the eastern tropical Pacific (Murua et al. 2016, Gershman et al. 2015), the emerging use of FADs with bycaught or otherwise dead marine mammals as bait has only recently been identified in small-scale fisheries of Ecuador and previously reported in a working document to the International Whaling Commission (Castro et al. 2018).

This study presents the first well-documented records on the take and use of cetaceans and pinnipeds as fishing bait in continental Ecuador. The purpose is to document and raise awareness about the occurrence of these illicit, unregulated and unreported practices, suggest regulations, and promote the adoption of management efforts to improve the protection of marine mammal populations in Ecuador.

\section{MATERIALS AND METHODS}

The information presented here was obtained by the Pacific Whale Foundation (PWF) with information from tourists, park rangers, and fishers and compiled as a database of stranding and bycatch records, observations through fish market monitoring as well as interviews with crew members of commercial fishing vessels and local fishermen. Strandings information, both from own observations and interviews with locals, was collected opportunistically in the course of multiple unscheduled visits to fishing ports, surrounding beaches and other coastal locations of continental Ecuador in the period 2009 to 2019 (Fig. 1, Table 1). Although daily search effort data were not logged, between June 2001 and March 2017 the carcasses of 130 cetaceans belonging to 18 species were documented in the PWF database as stranded on the coasts of continental Ecuador (Castro \& Van Waerebeek 2019). Only stranding records where we observed fishing gear, indications of baiting, cutting, tethering or other evidence of human manipulation, were taken into account in the present study. Cases 1

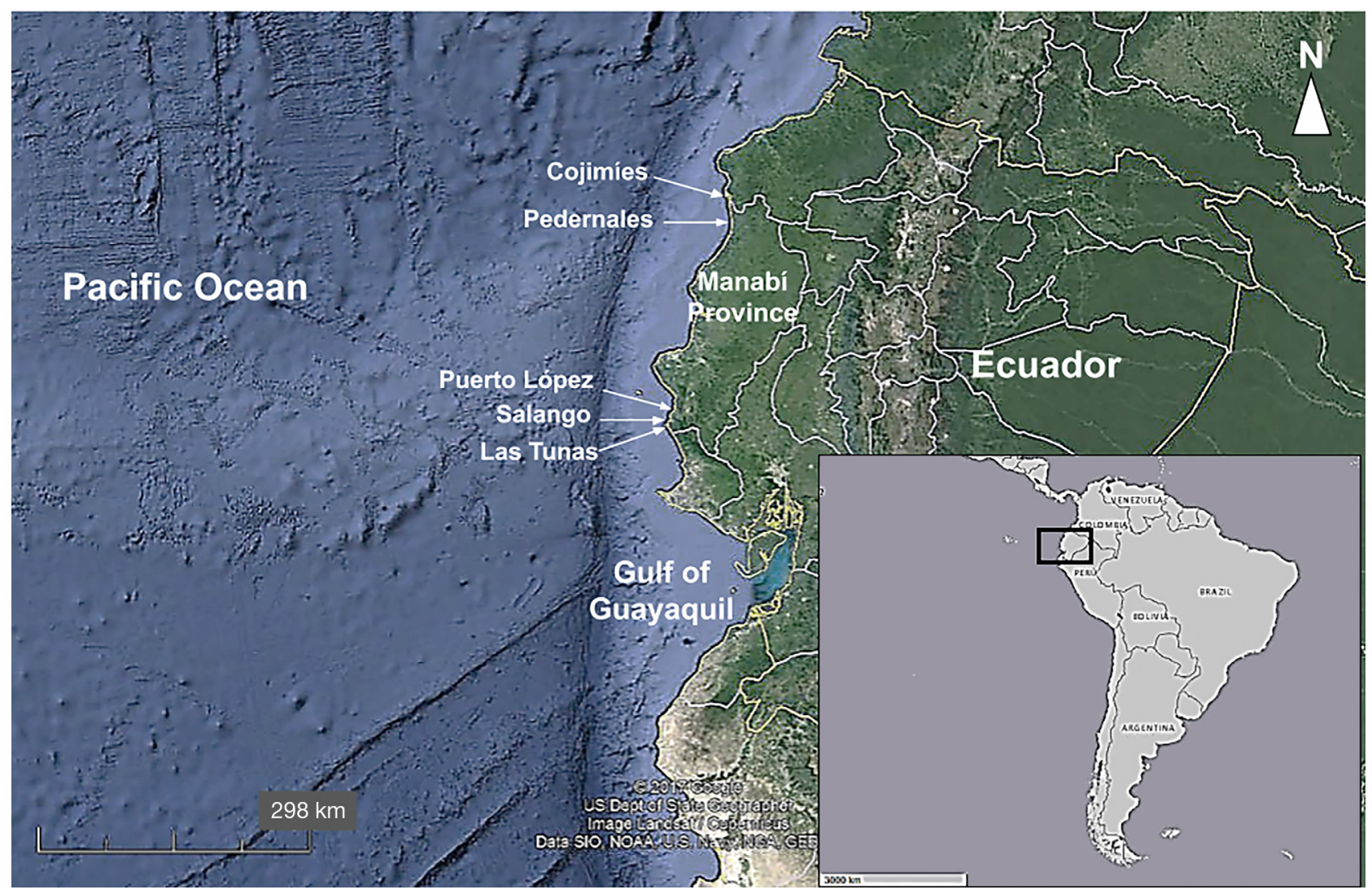

Fig. 1. Ecuador's continental coast showing the fishing villages and ports (Cojimíes, Pedernales, Puerto Lopez, Salango and Las Tunas) in Manabí Province, where cases of marine mammals used as bait and/or associated with improvised fish aggregating devices (IFADs) were found from 2009 to 2019 
Table 1. Documented cases of marine mammals utilized as bait with improvised Fish Aggregating Devices (IFADs) on the Ecuadorian coast from 2009 to 2019. Carcass condition codes (CC) follow Geraci \& Lounsbury (2005) - 1: alive, 2: freshly dead, 3: early decomposition, 4: advanced decomposition, 5: bare bones or mummified. Cases 2 and 9 are unconfirmed but highly probable cases. Conservation categories of the IUCN were based on IUCN (2019) at the international level and on various contributions to the Red Book of Ecuador's mammals (Tirira 2011) for the IUCN national categories in Ecuador. The CITES status was retrieved from the checklist of CITES Species (http://checklist.cites.org). N/A: not available

\begin{tabular}{|c|c|c|c|c|c|c|c|}
\hline Case & $\begin{array}{l}\text { Date } \\
\text { (d.mo.yr) }\end{array}$ & Location & $\begin{array}{l}\text { No. of } \\
\text { ind. }\end{array}$ & Species & $\mathrm{CC}$ & $\begin{array}{l}\text { IUCN category } \\
\text { (international/national) } \\
\text { CITES status }\end{array}$ & Observations \\
\hline 1 & 10.11 .09 & $\begin{array}{l}\text { Between Cojimíes } \\
\text { and Pedernales } \\
\left(0^{\circ} 22^{\prime} 4^{\prime \prime} \mathrm{N}, 80^{\circ} 2^{\prime} 7^{\prime \prime} \mathrm{W}\right)\end{array}$ & 17 & $\begin{array}{l}\text { South American } \\
\text { sea lion (Otaria byronia) }\end{array}$ & $3-4$ & $\begin{array}{l}\text { International: } \\
\text { Least Concern } \\
\text { National: N/A }\end{array}$ & $\begin{array}{l}\text { Carcasses associated with } \\
\text { ropes and buoys }\end{array}$ \\
\hline 2 & 10.11 .09 & $\begin{array}{l}\text { Between Cojimíes } \\
\text { and Pedernales } \\
\left(0^{\circ} 22^{\prime} 4^{\prime \prime} \mathrm{N}, 80^{\circ} 2^{\prime} 7^{\prime \prime} \mathrm{W}\right)\end{array}$ & 1 & $\begin{array}{l}\text { Sperm whale } \\
\text { (Physeter macro- } \\
\text { cephalus) }\end{array}$ & $3-4$ & $\begin{array}{l}\text { International: } \\
\text { Vulnerable } \\
\text { National: Vulnerable: } \\
\text { (Alava et al. 2011a) } \\
\text { CITES Appendix I }\end{array}$ & $\begin{array}{l}\text { Stranded carcass associated } \\
\text { with ropes and buoys; } \\
1 \text { marine turtle found nearby }\end{array}$ \\
\hline 3 & 23.11 .12 & $\begin{array}{l}\text { Puerto López } \\
\left(1^{\circ} 33^{\prime} 60^{\prime \prime} \mathrm{S},\right. \\
\left.80^{\circ} 48^{\prime} 60^{\prime \prime} \mathrm{W}\right)\end{array}$ & 1 & $\begin{array}{l}\text { Spotted dolphin } \\
\text { (Stenella attenuata) }\end{array}$ & 4 & $\begin{array}{l}\text { International: } \\
\text { Least Concern } \\
\text { National: Vulnerable } \\
\text { (Alava et al. 2011b) } \\
\text { CITES Appendix II }\end{array}$ & $\begin{array}{l}\text { Carcass and rope tied } \\
\text { tailstock }\end{array}$ \\
\hline 4 & 11.08 .14 & $\begin{array}{l}\text { Salango } \\
\left(1^{\circ} 35^{\prime} 0^{\prime \prime} \mathrm{S}, 80^{\circ} 51^{\prime} 0^{\prime \prime} \mathrm{W}\right)\end{array}$ & 1 & $\begin{array}{l}\text { Sea lion } \\
\text { (likely O. byronia) }\end{array}$ & $3-4$ & $\begin{array}{l}\text { International: } \\
\text { Least Concern } \\
\text { National: N/A }\end{array}$ & $\begin{array}{l}\text { Bloated animal floating with } \\
\text { holes and thin black rope } \\
\text { tied to the body }\end{array}$ \\
\hline 5 & 15.06 .16 & $\begin{array}{l}\text { Puerto López } \\
\left(1^{\circ} 33^{\prime} 60^{\prime \prime} \mathrm{S}, 80^{\circ} 48^{\prime} 60^{\prime \prime} \mathrm{W}\right)\end{array}$ & 1 & $\begin{array}{l}\text { Unidentified small } \\
\text { delphinid }\end{array}$ & 4 & & $\begin{array}{l}\text { Carcass exhibiting skin with } \\
\text { cut marks }\end{array}$ \\
\hline 6 & 17.09 .16 & $\begin{array}{l}\text { Puerto López } \\
\left(1^{\circ} 33^{\prime} 60^{\prime \prime} \mathrm{S}, 80^{\circ} 48^{\prime} 60^{\prime \prime} \mathrm{W}\right)\end{array}$ & ) & $\begin{array}{l}\text { Pygmy killer whale } \\
\text { (Feresa attenuata) }\end{array}$ & 4 & $\begin{array}{l}\text { International: } \\
\text { Least Concern } \\
\text { National: } \\
\text { Near Threatened } \\
\text { (Alava et al. 2011c) } \\
\text { CITES Appendix II }\end{array}$ & $\begin{array}{l}\text { The animal had its head } \\
\text { severed and missing tail }\end{array}$ \\
\hline 7 & 30.09 .16 & $\begin{array}{l}\text { Cojimies } \\
\left(2^{\circ} 20^{\prime} 0^{\prime \prime} \mathrm{N}, 80^{\circ} 02^{\prime} 00^{\prime \prime} \mathrm{W}\right)\end{array}$ & 7 & $\begin{array}{l}\text { Sea lion } \\
\text { (likely to be } O \text {. byronia) }\end{array}$ & $3-4$ & $\begin{array}{l}\text { International: } \\
\text { Least Concern } \\
\text { National: N/A }\end{array}$ & $\begin{array}{l}\text { Skeletal remains and car- } \\
\text { casses entangled with nylon } \\
\text { rope connected with weights } \\
\text { and buoys. Presence of float } \\
\text { tanks, purse seine or gillnet, } \\
\text { and wooden structure with } \\
\text { floats. Four more sea lions } \\
\text { were found nearby }\end{array}$ \\
\hline 8 & 30.09 .16 & $\begin{array}{l}\text { Cojimies } \\
\left(2^{\circ} 20^{\prime} 0^{\prime \prime} \mathrm{N}, 80^{\circ} 02^{\prime} 00^{\prime \prime} \mathrm{W}\right)\end{array}$ & 1 & $\begin{array}{l}\text { Short-finned pilot whale } \\
\text { (Globicephala macro- } \\
\text { rhynchus) }\end{array}$ & $3-4$ & $\begin{array}{l}\text { International: } \\
\text { Least Concern } \\
\text { National: } \\
\text { Near Threatened } \\
\text { (Castro et al. 2011a) } \\
\text { CITES Appendix II }\end{array}$ & $\begin{array}{l}\text { Carcass with both dorsal fin } \\
\text { and flukes missing; } \\
\text { presumably a shark bite and } \\
\text { other damage. Rope, } \\
\text { weights, and buoys, as part } \\
\text { of a FAD, were attached. } \\
3 \text { dead sea turtles were } \\
\text { found at the same location }\end{array}$ \\
\hline 9 & 28.07 .19 & $\begin{array}{l}\text { Las Tunas } \\
\left(1^{\circ} 39^{\prime} 0^{\prime \prime} \mathrm{S}, 80^{\circ} 49^{\prime} 15^{\prime \prime} \mathrm{W}\right)\end{array}$ & 1 & $\begin{array}{l}\text { Immature humpback } \\
\text { whale (Megaptera } \\
\text { novaeangliae) }\end{array}$ & 4 & $\begin{array}{l}\text { International: } \\
\text { Least Concern } \\
\text { National: Vulnerable } \\
\text { (Castro et al. 2011b) } \\
\text { CITES Appendix I }\end{array}$ & $\begin{array}{l}\text { Carcass washed ashore with } \\
\text { shark bites but no other } \\
\text { visible traumata; light nylon } \\
\text { line attached to the tailstock. } \\
\text { Presumably collected and } \\
\text { used by fishermen }\end{array}$ \\
\hline
\end{tabular}


and 2 are based on information received from the Municipality of Pedernales, Manabí province (Fig. 1) and examination of photos for these specific cases (Table 1) available online (information published by the newspaper El Diario 2009). Condition codes of carcasses (CC) were determined according to Geraci \& Lounsbury (2005), briefly, as follows: 1: alive; 2: reshly dead; 3: early decomposition; 4: advanced decomposition; 5 : bare bones or mummified.

A FAD is defined as a floating man-made object or structure used to attract ocean going pelagic fish, such as tuna, billfish, and dorado. They usually consist of buoys or floats tethered to the ocean floor with concrete blocks. Industrial fisheries utilize large, commercially produced FADs made of metal and plastic floats, so they can be used for long periods (Morgan 2011a, Moreno et al. 2016a); however, there is a recent tendency to replace these fishing devices with biodegradable materials such as bamboo, palm leaves, coconut fiber, and cotton (Moreno et al. 2016b, Murua et al. 2016). For instance, efforts to test and implement biodegradable FADs are underway in Ecuador (Tunacons 2019). Once deployed at sea, they are rarely lifted out of the water.

\section{RESULTS}

\subsection{Marine mammals as bait}

We found that smaller, improvised FADs (IFADs) fabricated and used by artisanal fishers (Fig. 2) were often baited with marine mammal remains. Nine cases of marine mammal strandings that had been used as bait (2 suspected) were registered at 4 different locations along the coast of Manabí Province, i.e. Cojimíes-Pedernales, Puerto López, Salango and Las Tunas (i.e. from $1^{\circ} 39^{\prime} 0^{\prime \prime} \mathrm{S}, 80^{\circ} 49^{\prime} 15^{\prime \prime} \mathrm{W}$ at Las Tunas to $0^{\circ} 22^{\prime} 4^{\prime \prime} \mathrm{N}$, $80^{\circ} 2^{\prime} 7^{\prime \prime} \mathrm{W}$ at Cojimíes-Pedernales) from 2009 to 2019 (Table 1, Fig. 1), but with strandings survey effort since 2001. When found washed ashore or floating nearshore, carcasses were either directly attached to a FAD or wrapped in some assemblage of fish netting, lines, and buoys, with clear indications that they had been handled by people and were not simply the result of accidental entanglement in fishing gear (Figs. 3-6).

In total, 31 individuals of 6 (potentially 7) different marine mammal species were determined as used for bait associated with a FAD. The species most frequently encountered was South American sea lion Otaria byronia, with a prevalence rate of $80.6 \%$ (i.e. 25 out of 31 individuals) relative to the total number of carcasses observed (Figs. 3 \& 5), but 3, potentially 4 , species of Delphinidae were also found: 1 pantropical spotted dolphin Stenella attenuata (Fig. 4A), 1 unidentified small delphinid (Fig. 4C,D), a short-finned pilot whale Globicephala macrorhynchus (Fig. 4E,F), and a pygmy killer whale Feresa attenuata, accounting for $19.4 \%$ of the reported carcasses identified as FAD bait (Table 1). Two large cetaceans, including an odontocete (sperm whale Physeter macrocephalus) and mysticete (humpback whale Megaptera novaeangliae), were probably found floating at sea and may have been opportunis-

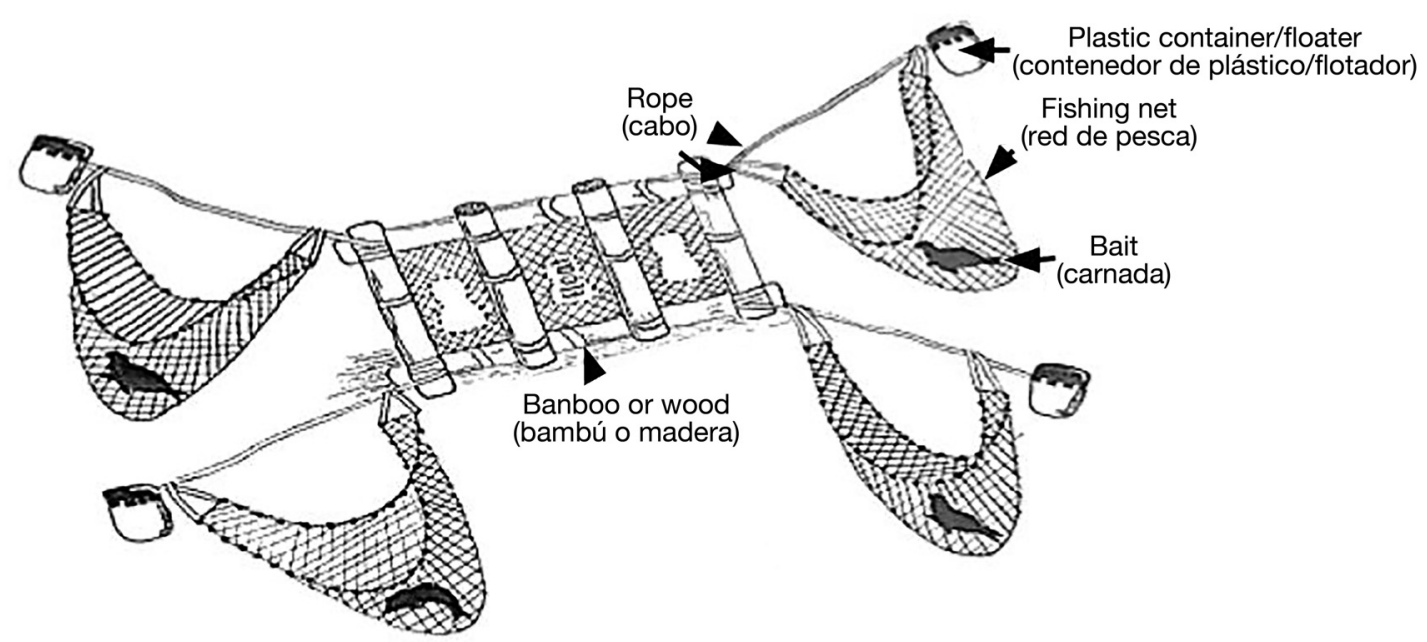

Fig. 2. Conceptual illustration of the improvised fish aggregating device (IFAD) found on Cojimíes Beach, Ecuador, on 9 November 2009. The IFAD is assembled as a rectangular or square wooden raft or platform made of bamboo or wood fully or partially covered and wrapped with mesh netting and tied up with ropes along the perimeter of the raft; gillnets or other fishing nets with floats (plastic containers or bins), containing dead bodies or remains of marine mammals as bait, are connected through ropes to the 4 corners of the raft. Illustrator: Alejandra Loaiza 
tically exploited as IFADs by artisanal fishers. This may be a common practice considering that accidental entanglements and ship strikes of sperm and humpback whales have been occurring frequently in Ecuador for decades (e.g. Haase \& Félix 1994, Alava et al. 2005a, 2012, Félix et al. 1997, Castro \& Van Waerebeek 2019). On 2 occasions, more than 1 large marine vertebrate was found associated with IFAD parts and gear on the same beach in Cojimíes, Manabi Province (Table 1). The animals associated with IFADs had washed ashore, or were found floating nearshore, as shown in Figs. 3-5, with remains of ropes, floats, and weights, which in some cases were attached to a still intact IFAD (Figs. 4 \& 5). Comparing the total number of stranded, dead marine mammals (i.e. 5 cetaceans and 25 sea lions) associated with IFADs as bait $(\mathrm{n}=30$ individuals, excluding the humpback whale reported in 2019; Table 1) to the total number of marine mammal strandings $(\mathrm{n}=168$ individuals, including cetaceans and pinnipeds such as O. byronia and Arctocephalus sp.) from 2001 to 2017 (Castro \& Van Waerebeek 2019, PWF database unpubl. data), it is roughly estimated that approximately $18 \%$ of stranded marine mammals were associated with IFADs.

The carcasses were mainly in an advanced state of decomposition (condition code, C.C. $=4$ ), as most had apparently been found some time after the stranding occurred, their skin was sunburnt, and many showed holes typically made by scavenging

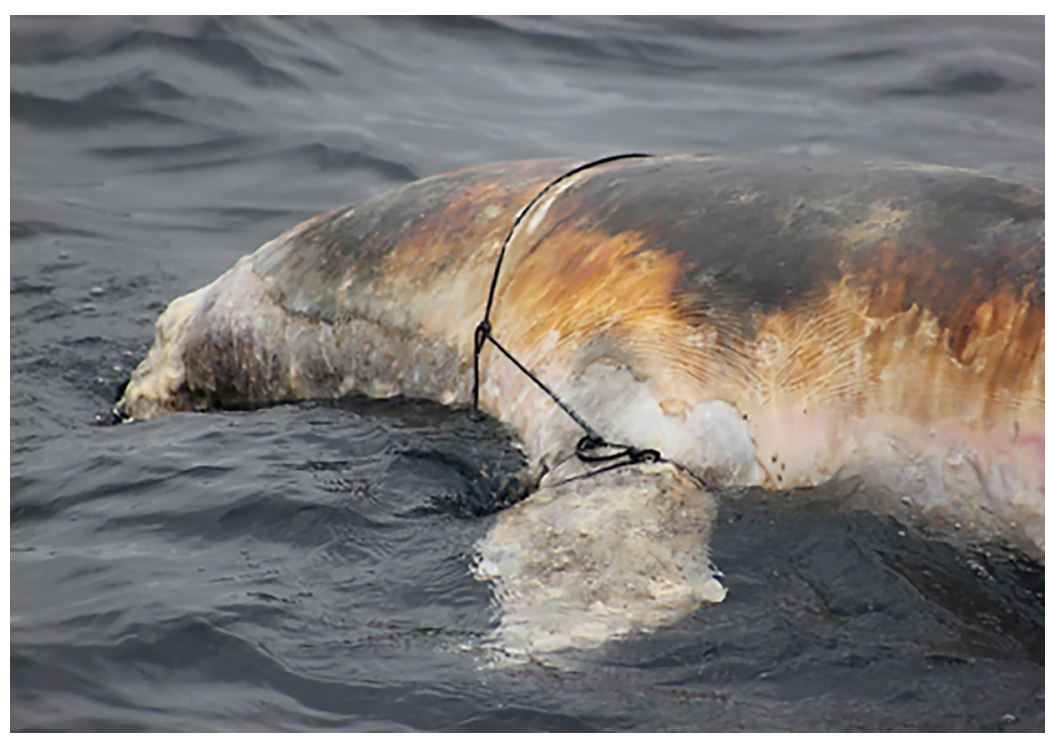

Fig. 3. The decomposing body of a South American sea lion (Case 4) found floating near Isla Salango on 11 August 2014. A nylon rope was tied (not entangled) around the forebody and around the base of the pectoral fins. Photo: Pacific Whale Foundation ghost crabs (Ocypodidae) and black turkey vultures Coragyps atratus, which are common on Ecuador's beaches. Also, some bare bones were found wrapped in small-mesh netting tied to large floats (Case 7; Fig. 5) where all soft tissues had already been scavenged by fishes or other marine organisms. Certain cases deserve further comments, as follows.

Case 1. On 9 November 2009, the regional newspaper 'El Diario' published an article on the stranding of 17 sea lions, 1 sperm whale and 1 sea turtle (unidentified species) on the beach between Cojimíes and Pedernales, Manabí Province. Unfortunately, the dead animals were in an advanced state of decomposition and quickly buried without necropsy or scientific analysis. This seems to be the earliest reported stranding event related to the use of marine mammals as FAD bait in Ecuador. The Municipality of Pedernales first raised the notion that the cause of those strandings was associated with the use of FADs by fishers (El Diario 2009). Although $>1$ IFAD was likely involved, we continued treating this as a single case.

Cases 7 \& 8. Another multiple-species FAD stranding consisting of 7 sea lions (probably South American sea lions $O$. byronia) and a short-finned pilot whale, alongside 3 unidentified sea turtles was registered in Cojimíes in September 2016 (Table 1). Five sea lions were tied with thin ropes to the same structure, with weights and floats; the 2 others were found detached along the same beach (Fig. 5A-D). The skeletal remains of some sea lions were wrapped in netting tied to a wooden structure with floats and a tank (Figs. 5E-G). The pilot whale had cuts in the dorsal fin and tail, possibly where it was tied to the structure or some floating tank (Fig. 4E,F). Several components used in IFADs were observed as shown in Fig. 5C-G. The IFAD was found on the beach attached to green plastic flotation tanks (Fig. 5G). Black gillnet-like netting holding the complete carcasses of sea lions was found attached at both sides (Fig. 5E). In one net, only bare bones were found, suggesting that perhaps this bait was in place for an extended time (Fig. 5G). The origin of the FAD is unknown, but due to its size, it is likely that it was being used by a larger fishing boat before it was lost or broke loose from its moorings and then washed ashore. 


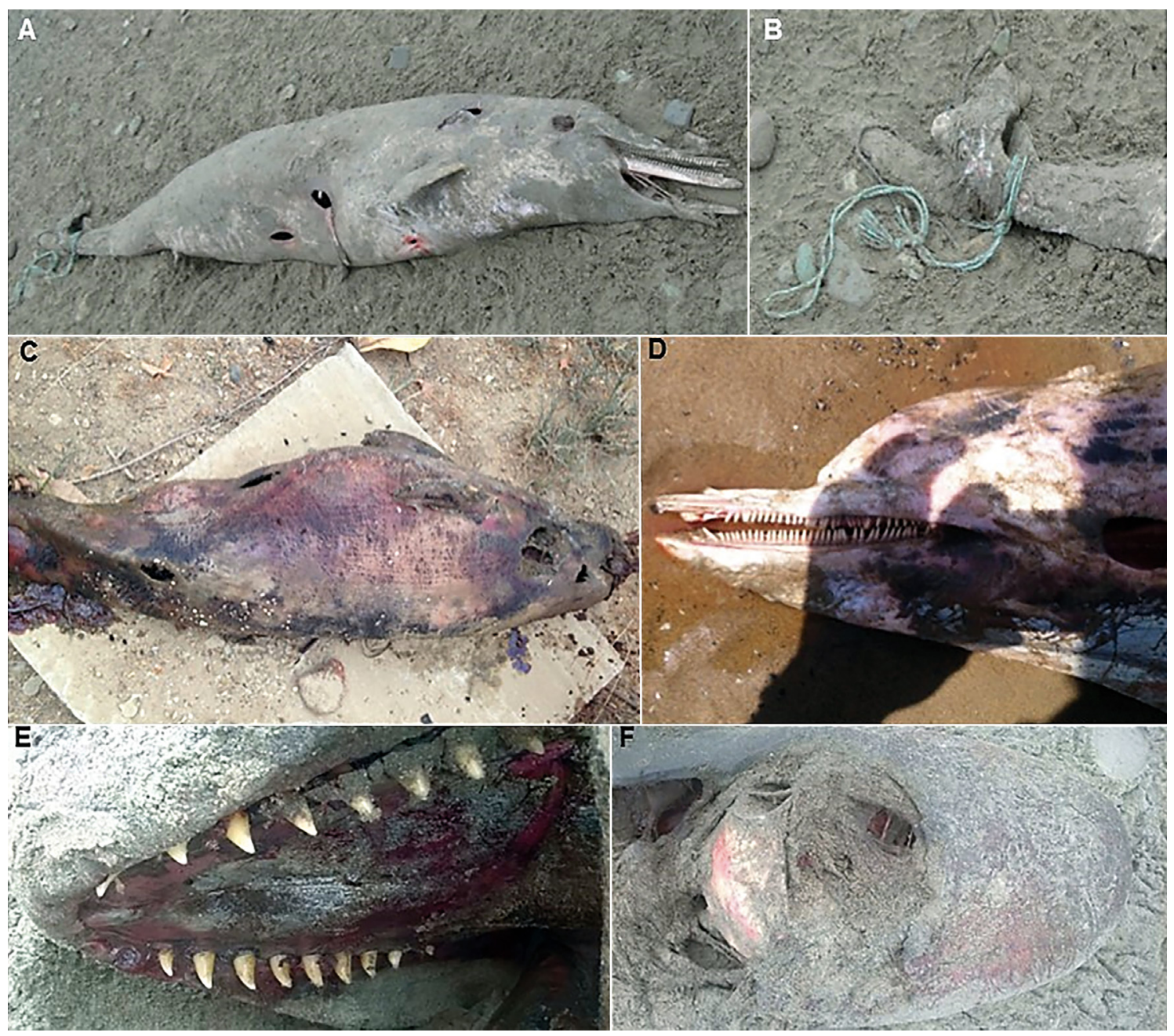

Fig. 4. Carcasses and remains of cetacean species associated with and used as bait in improvised fish aggregating devices (IFADs). (A) Pantropical spotted dolphin (Case 3) as found on a Puerto López beach, on 23 November 2012; (B) the dolphin had green nylon rope firmly tied to its tailstock, and floats attached (not shown here). (C, D) Body and head of unidentified delphinid (Case 5) found stranded at Puerto López on 15 June 2016; the body showed cut marks and sunburn. (E) Anterior upper jaw of juvenile short-finned pilot whale (Case 8) found at fishing port of Puerto López; (F) evident cut-marks on the shortfinned pilot whale indicated utilization, almost certainly for baiting FADs. Note bulbous head in dorsal view consistent with G. macrorhynchus, which is also thought to be a bycatch victim. Photos: Pacific Whale Foundation

Case 9. The single wrap of a $7-8 \mathrm{~mm}$ nylon cord around the tailstock of the subadult humpback whale appeared to be a human intervention on a carcass (Fig. 6A). A live whale of this size would have readily snapped such a light line had it been an accidental entanglement with fishing gear. However, this cord is thought to have held a dead floating whale tethered as a Type 1 FAD (see Section 3.2) to some fishing gear. Local rangers (Machalilla National Park) blamed the industrial fishery (pers. comm. to KVW); however, no evidence puts the artisanal fishery beyond suspicion. The cause of death of the whale remained unknown, but ventrally no signs of traumata were visible except (most likely postmortem) shark bites (Fig. 6B). Unfortunately, no necropsy could be performed as the carcass was quickly buried on the beach by a Municipality backhoe loader.

\subsection{Improvised fish aggregating devices}

Artisanal fishermen do not seem to invest in the large commercially available FADs. Instead, they make their own: far simpler and smaller versions (Figs. $2 \& 4 \mathrm{E}, \mathrm{F}$ ), which we refer to as improvised fish aggregating devices (IFADs). We suggest that most of the latter are baited with the remains of marine mammals or sea turtles, often involving several 

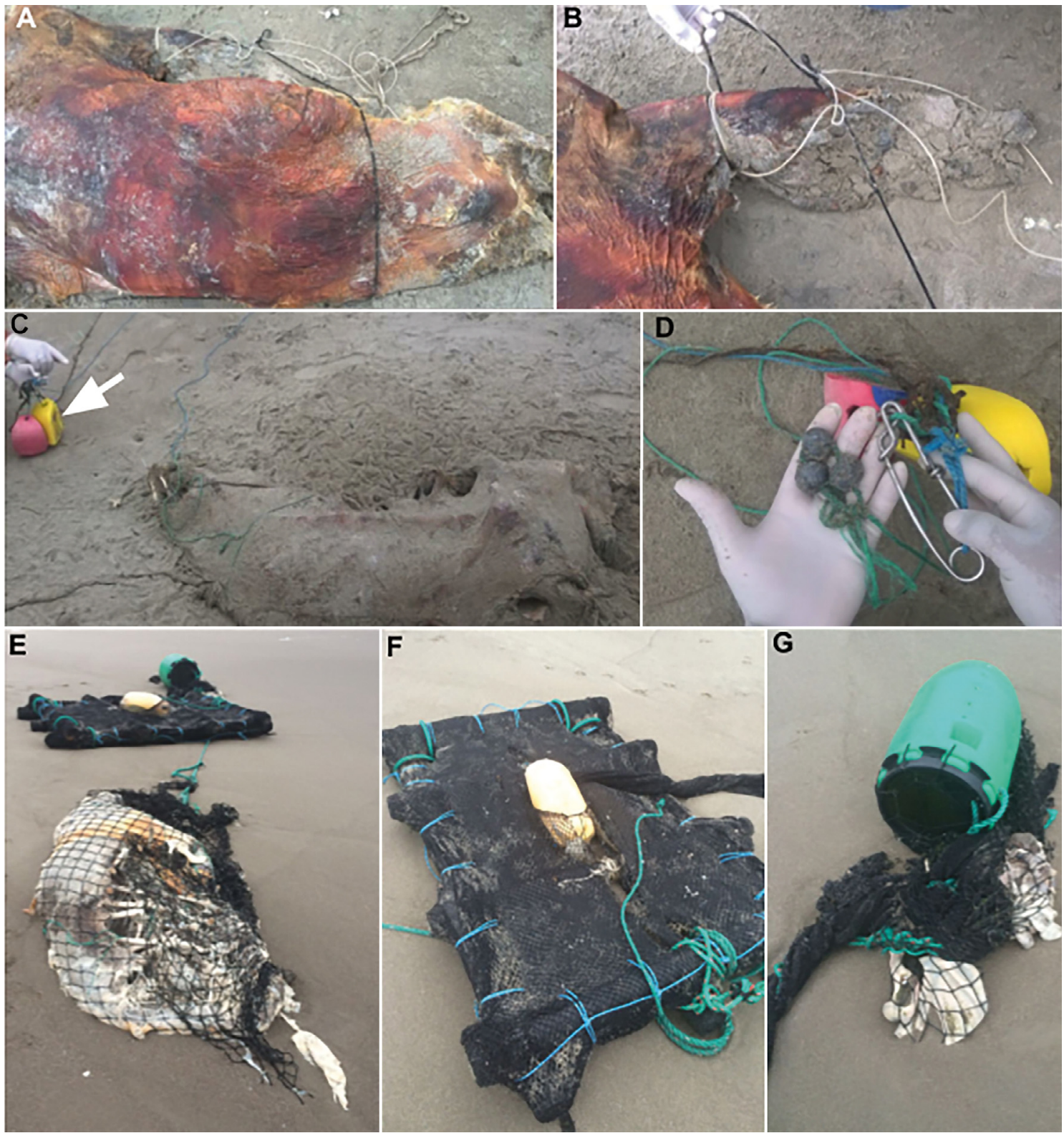

Fig. 5. Carcasses and skeletal remains of sea lions (probably South American sea lions, Otaria byronia) used as bait in improvised fish aggregating devices (IFADs) (Case 7). (A,B,C) Two of 7 sea lions (Case 7) found in association with IFADs on Cojimíes beach on 30 September 2016. Note (A) a black rope wrapped around the body and (B) the presence of white nylon rope doubly wrapped and knotted around the flippers (not accidentally entangled). (C) Floats were attached to the lines (white arrow), and (D) lead weights were also present. At least 4 different colored lines were used. (E,F,G) The skeletal remains of 2 sea lions $(E, G)$ were also attached to the IFADs with recognizable pinniped scapula, humerus, and ribs, wrapped in smallmesh netting. (F,G) Note the assembled raft covered with black mesh tied up with blue and green ropes and a yellow float on it. (G) A green plastic bin used as a float, tied to mesh netting with green ropes and attached to the raft was also found. Photos A-D by Pacific Whale Foundation. Photos E, F, and G courtesy of Johana Moreira, Ministry of Environment of Ecuador

specimens simultaneously (see illustration in Fig. 2). Based on field observations and comments provided by fishers, we provisionally distinguish 3 types of IFADs found washed ashore, the difference being the presence or absence of floats and the type of construction and materials used.
Type 1. Marine mammal carcasses moored with thin ropes by their pectoral fins, body or tailstock. They are possibly moored to certain fishing gear, and they remain floating by their own decompositionenhanced buoyancy, attracting fish. No floats are present. This type of IFAD is used by artisanal fishers 

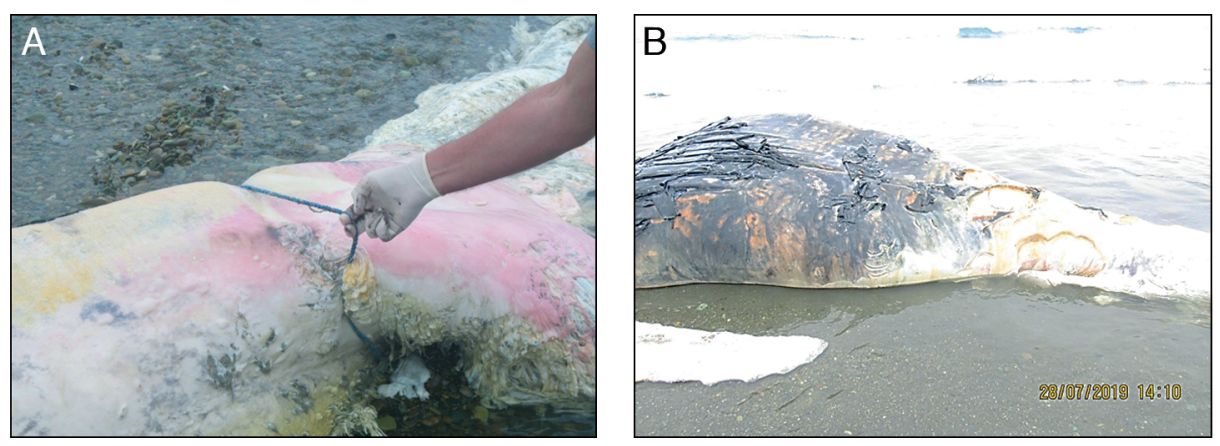

Fig. 6. (A) Carcass of a subadult humpback whale with a nylon cord around the tailstock found in Las Tunas beach on 28 July 2019. (B) Note the ventral view of the whale with tailstock showing evidence of shark scavenging. Photos: Pacific Whale Foundation (A) \& K. Van Waerebeek (B)

(Figs. 3 \& 4B). We suspect that floating dead whales may be used in this way, such as the sperm and humpback whales found stranded in Pedernales and Las Tunas, respectively.

Type 2. Marine mammals wrapped in netting and tied to plastic floats to increase and prolong buoyancy. The nets are heavier and have weights and floats with mooring lines. Possibly used by artisanal fishermen, chinchorreros and others (Fig. 5A-C).

Type 3. Marine mammals wrapped in fishing nets but at the same time tied to floats supporting larger, mostly rectangular wooden and bamboo structures, which can hold several bait-carcasses simultaneously (Fig. 5E-G); possibly used also by larger, semi-industrial fishing boats.

Although no observations have been made of operating baited FADs at sea, they are thought to function by attracting smaller marine organisms including small fish to feed on the bait, which then, in turn, may attract and concentrate larger fish species (tuna, billfishes, and sharks). The latter are easily encircled by purse-seines or taken by other means (e.g. long-lines), as is done with commercial FADs.

Interviews with artisanal fishers revealed that small cetaceans are obtained from incidental captures in fishing nets, while sea lions if still alive following net entanglement were beaten to death. According to some artisanal fishers, the use of marine mammals as bait is carried out only by industrial tuna fisheries and 'chinchorreros' (purse-seine) who take advantage of the night to opportunistically fish for other species such as dorado using FADs. The name in Spanish for this kind of FAD is 'plantado' (Morgan 2011b). However, some interviews revealed that artisanal fishermen were also using small cetaceans and sea lions obtained opportunistically, referred to as 'siembra'. Thus, the words 'plantado' and 'siembra' are synonyms, applied to industrial or artisanal fishing, respectively.

Based on anecdotal information from fishers, the use of dead marine mammals as bait in FADs is very effective, due to their strong smell, high amount of fat and long permanence in the water. An interviewed fisher from Puerto López stated: 'The best thing to catch dorado fish is the fat of sea lions and dolphins, with which [the FAD] is baited as these remains stay intact for several days'.

\section{DISCUSSION}

Here we reported the first cases of cetaceans and sea lions used as bait in IFADs in artisanal fisheries in Ecuador. Several questions were raised by our findings. The main concern is to what extent improvised FADs are used by Ecuadorean artisanal fisheries and since when. Also, the incidence of baiting IFADs, whether it is standard practice or only an occasional one, remains unclear. As it stands, the available evidence is insufficient to clarify if the observed mixed-species arrangements were a coincidence or were arranged by design. Conceivably, each bait species may have different characteristics, e.g. decompose at a different pace, preferentially attract different marine organisms, or other.

In 2 cases (Cases 2 and 8), dead sea turtles were also observed washed ashore in close association with IFADs (Table 1), raising the question whether they were also applied as bait. If so, these would be the first reports that we know of. However, since these marine reptiles are confirmed entanglement victims of commercial FADs drifting in open waters (Fonteneau et al. 2013), it is challenging to uncover the causality of their presence in and around the stranded IFADs described here. As accidental entan- 
glements cannot be excluded, more field research will be needed to provide the necessary answers. Indeed, the issue is further confounded by insights from other sea turtle stranding events along Ecuador's coast. Strandings of olive ridley Lepidochelys olivacea and green sea turtles Chelonia mydas are common on Ecuador's beaches (see Alava et al. 2005b). Massive die-offs have also been documented (Alava et al. 2005b, Herrera et al. 1999). These stranding episodes were associated with environmental/natural factors (e.g. changes in sea surface temperature, food availability, parasitic and other diseases) and anthropogenic impacts, including fisheries interactions, mainly bycatch in gillnets and longlines, and boat collisions (Herrera et al. 1999, Alava 2000, Alava et al. 2005b). While the FADs used by industrial fisheries in Ecuador have begun to be managed and regulated by the IATTC (Gershman et al. 2015, 2016, 2018, Murua et al. 2016), artisanal fishers have requested regulation from the Ecuadorian Government (Castro et al. 2018). There are indications that industrial fishers may also have started to bait FADs to increase effectiveness, but this has not been substantiated. It is reasonable to believe that the lack of enforcement of relevant legislation, regulation, and control regarding the use of FADs may have allowed artisanal fishermen in Ecuador to start using baited IFADs so as to improve their fishing operations. It will be difficult to study the extent of use and evaluate the impact of this activity considering that the IFADs are hard to visibly trace when deployed at sea. Indeed, the few IFADs that were documented had reached the shore and were encountered by chance. A well-designed interview study might shed some light on these aspects, but a considerable degree of resistance and some false declarations should be expected.

Little is known of the potential use of baited FADs in waters of neighboring countries and where this practice first arose. There is no evidence, for instance, that baited FADs are or have been deployed off Peru, Chile, or Colombia. However, the use of small cetaceans as bait in longline fisheries, especially for sharks, has long been widespread in Peru (e.g. Van Waerebeek \& Reyes 1994, Van Waerebeek et al. 2002, Mangel et al. 2010) and was also documented in Pacific Colombia (Avila et al. 2008). More recently, Peruvian gillnet fishermen have resorted to attaching butchered parts of small cetaceans directly to wide-mesh multifilament gillnets to attract sharks, rays, and other large fishes; in some ways these are similar to a Type 1 improvised FAD, but structured FAD devices with floats (Type 2 and 3 ) have so far not been documented. In a survey of fishing operations of some artisanal fishing boats in Salaverry in 2005 to 2007, Mangel et al. (2010) found that $29 \%$ of small cetaceans by-caught in gillnets were used as bait. Also, all harpooned dolphins, both by gillnet and longline vessels, were used as bait (Mangel et al. 2010).

The direct hunting (harpooning) of bottlenose dolphins for trading of meat as bait in the Gulf of Guayaquil has also been documented and anecdotally reported by artisanal fishers and rangers, but the current status of this practice has yet to be concertedly assessed in coastal Ecuador (Van Waerebeek et al. 1997, Jiménez et al. 2018). Previous evidence indicated that some fishers were eager to pay up to USD $\$ 75$ for a dolphin carcass to obtain bait in a fishing community (i.e. Puerto López) on the central coast of Ecuador during the 1990s (Félix \& Samaniego 1994). However, questions remain concerning the presence of a systematic market to trade bait collected from bycaught small cetaceans, and it is likely that a small-scale black market took place on the southern coast of Ecuador, i.e. Puerto Bolívar (Félix \& Samaniego 1994, Van Waerebeek et al. 1997), where at least one boat harpooned dolphins in the past (Van Waerebeek et al. 1997); similarly, at least one bottlenose dolphin was harpooned by fishers close to Puna Island, Gulf of Guayaquil (Van Waerebeek et al. 1997). As it stands, the use of a cast net (a fishing gear locally known as 'voladora') by a fisher from Posorja Harbor (Guayaquil Gulf) to directly take bottlenose dolphins to trade their meat in local markets was reported by rangers from the Reserva Ecológica de Vida Silvestre Manglares El Morro (El Morro Mangrove Wildlife Ecological Reserve) in 2017 (Jiménez et al. 2018). The exact purpose remains unclear, i.e. whether bycaught or hunted marine mammals are being traded for their use in FADs in Ecuador. Recent anecdotal information, archived in a recorded interview of an artisanal fisher working on a tuna fishing boat, corroborates that this seems to be the case for South American sea lions taken in Peruvian waters. Excerpts from the interview are provided as follows:

'Here, the 'lobos marinos' [sea lions] for 'plantados' [the FADs] are brought from Piura, or Pisco (Peru); the sea lions are bought from small boats in Peru that are dedicated to the dorado fisheries. There, they call the dorado 'perico'. Nowadays they buy the sea lions during the 'brisa' fishing period; they purchase them from the small vessels, then the sea lions are frozen and stored to be used for the 'plantados'. The 'brisa' is a 'cardumen', a specific school of tuna fish that occur 
on these dates, from December to January... A sea lion is cheap and costs between USD \$ 70 to 100 each one, which is a lot of money for the Peruvian fishers; they buy between 40 to 50 sea lions, depending on the amount of sea lions available for sale by the fishers in the boats. The sea lions are not taken in Ecuador as there are very few here and the species is more regulated by the authorities; the sea lions are from Peru where they are very abundant and not regulated, except for the surveillance of the Peruvian Navy... Between December and January until midFebruary, during the brisa period, the sea lions are bought' (J. M. confidential pers. comm. to C. Castro).

Although no evidence or assessment is presently available regarding the use of FADs in artisanal fishing operations in Ecuador, we suspect that both the coastal gillnet fisheries and the large oceanic longline fisheries, targeting large pelagic fish such as tuna, billfishes, and various shark species, may be the main users of IFADs. This rationale is based on the fact that the artisanal fisheries fleet usually operates within the 200 nautical miles (nm) of Ecuador's Economic Exclusive Zone (EEZ), including the coastal multifilament gillnet fisheries and the oceanic artisanal longline fisheries fleet (Alava et al. 2015, Martínez-Ortiz et al. 2015). However, it is likely that the artisanal fisheries fleet is currently expanding its fishing operations beyond the $200 \mathrm{~nm}$, specifically the large oceanic artisanal longline fishery which is unique to Ecuador and operates far offshore deploying a mothership with a fleet of small vessels (Alava et al. 2015, Martínez-Ortiz et al. 2015). Assuming the wide distribution of fishing zones and extension of artisanal fishing fleet off Ecuador's continental coast as a proxy, we project that IFADs may also be used in these fishing areas.

The overall scarcity of information begs for more thorough fact-finding investigations that could then serve as guidance to propose legislation that would control or prohibit the use of marine mammals as bait, search for alternatives and recommendations, and establish exemplary sanctions. As it stands, the deployment of FADs using marine mammals as bait in Ecuador can have negative repercussions in the face of new regulations established in 2017 under the US Marine Mammal Protection Act (NMFS 2016), commanding the implementation of a regulatory program to monitor and mitigate marine mammals bycatch in countries exporting seafood/fish to the USA by 2022. Ecuador falls in this categoy as this nation exports seafood to the USA but has not yet implemented such a regulatory program (Jiménez et al. 2018).
Since 2013, the IATTC, as the regional fisheries management organization (RFMO) in the Eastern Tropical Pacific, recommended the use of non-entangling drifting FADs as a measure to mitigate the entanglement and minimize deleterious damage to susceptible marine fauna (Gershman et al. 2015, Murua et al. 2016). Along with this measure, incentives for marine observers and fishers should be developed and fostered by local fisheries management authorities, so as to record and retrieve abandoned, lost or discarded fishing gear, including derelict drifting FADs encountered at sea, and to deliver the derelict fishing gear to port reception facilities for recycling and disposal (Gilman 2015, Gilman et al. 2016). The precautionary principle has been emphasized as an approach to reduce, or at least monitor and control, the use of dFADs to mitigate their adverse effects not only on yellowfin and bigeye tuna stocks, sharks and sea turtles but also on open-ocean ecosystems (Fonteneau et al. 2013). As an option, the International Seafood Sustainability Foundation has also recommended the use of nonentangling biodegradable FADS, with minimal risk of entanglement, constructed using only natural and/or biodegradable materials (e.g. bamboo, sisal, yute, palm leaves, coconut fiber, cotton) instead of plastics and/or metals to further reduce and avoid the environmental impact of marine pollution by drifting FADs on the oceans (Murua et al. 2016, Moreno et al. 2016b). In October 2018, Ecuador's Tuna Conservation Group launched a contest aimed at developing biodegradable FADs (Eco-FADs) for industrial fisheries, especially tuna fishing in Ecuador to reduce pollution (Tunacons 2019). Experiments by tuna processing companies with certain biodegradable and plant materials to test the designs are underway in the country. Similar mitigation actions and incentives should be promoted among small-scale (artisanal) fishers by fisheries management authorities.

The issue of marine mammal-baited IFADs has recently emerged as a threat to the conservation of marine mammals in Ecuador and should be addressed. As estimated in this study, approximately a fifth of dead marine mammals found stranded along Ecuador's beaches were associated with IFADs over the period 2001 to 2017. If not addressed, within a short period of time, illicit directed takes of both cetaceans and pinnipeds could increase dramatically and lead to severe conservation problems for Ecuador's marine mammal populations. Community-based conservation including an open, bottomup dialogue is required urgently between Ecuador's artisanal fishing communities and fisheries manage- 
ment actors assisted by experts. These should provide insights into the pervasiveness of IFAD use and the origin of marine mammal-sourced bait, as well as test and evaluate alternative bait (e.g. low-cost frozen abattoir remains considered unfit for consumption) and fully biodegradable IFAD materials. Finally, these approaches can serve as potential recommendations to deter and help prevent the use of marine mammals as bait.

Acknowledgements. This work is dedicated to the memory of the late Gregory Kaufman, who was a great colleague and devoted researcher from the Pacific Whale Foundation. We thank the volunteers of the Pacific Whale Foundation and park rangers, especially Johana Moreira and Ruben Aleman, for their tenacity and dedication in obtaining data. Ben Haase is acknowledged for confirming Otaria byronia as the most frequent pinniped in Ecuador's continental waters, and Julio C. Reyes for providing a helpful taxonomic opinion about some problematic photographs. Special thanks to Gregory Kaufman for providing valuable insights and edits to an earlier version of this manuscript. Alejandra Loaiza C. is thanked for preparing the FAD illustration.

\section{LITERATURE CITED}

Alava JJ (2000) Estado actual de conservación de las tortugas marinas en El Ecuador [Current conservation status of sea turtles in Ecuador]. In: Amorocho D, Campo F, Riascos JA, Parra E (eds) Memorias del Curso Taller en Biología y Conservación de las Tortugas Marinas y III Seminario Internacional de la Red Colombiana para la Conservación de las Tortugas Marinas [Proceedings of the Workshop about Biology and Conservation of Sea Turtles and III International Seminar of the Colombian Network for the Sea Turtles Conservation]. RETOMARWIDECAST Association, Colombia, p 51-58

Alava JJ, Barragan MJ, Castro C, Carvajal R (2005a) A note on strandings and entanglements of humpback whales (Megaptera novaeangliae) in Ecuador. J Cetacean Res Manag 7:163-168

Alava JJ, Jiménez P, Peñafiel M, Aguirre W, Amador P (2005b) Sea turtle strandings and mortality in Ecuador: 1994-1999. Mar Turtle Newsl 108:4-7

Alava JJ, Haase B, Utreras V, Merlen G, Tirira DG (2011a) Sperm whale (Physeter macrocephalus). In: Tirira DG (ed) The red book of Ecuadorian mammals, 2nd edn. Fundación Mamíferos y Conservación, Pontificia Universidad Católica del Ecuador y Ministerio del Ambiente del Ecuador, Quito, p 241-242 (in Spanish)

Alava JJ, Castro C, Denkinger J, Haase B and others (2011b) Pantropical spotted dolphin (Stenella attenuata). In: Tirira DG (ed) The red book of Ecuadorian mammals, 2nd edn. Fundación Mamíferos y Conservación, Pontificia Universidad Católica del Ecuador y Ministerio del Ambiente del Ecuador, Quito, p 237-238 (in Spanish)
Alava JJ, Denkinger J, Haase B, Utreras V, Tirira DG (2011c) Pygmy killer whale (Feresa attenuata). In: Tirira DG (ed) The red book of Ecuadorian mammals, 2nd edn. Fundación Mamíferos y Conservación, Pontificia Universidad Católica del Ecuador y Ministerio del Ambiente del Ecuador, Quito, p 275 (in Spanish)

* Alava JJ, Barragán M, Denkinger J (2012) Assessing the impact of bycatch on Ecuadorian humpback whale breeding stock: a review with management recommendations. Ocean Coast Manage 57:34-43

Alava JJ, Lindop A, Jacquet J (2015) Reconstruction of marine fisheries catches for continental Ecuador, 1950-2010. UBC Fisheries Centre Working Paper \# 2015-34. University of British Columbia, Vancouver

Alava JJ, Tatar B, Barragán MJ, Castro C and others (2019) Mitigating cetacean bycatch in coastal Ecuador: governance challenges for small-scale fisheries. Mar Policy 110:025

Avila IC, García C, Bastidas JC (2008) A note on the use of dolphins as bait in the artisanal fisheries off Bahía Solano, Chocó, Colombia. J Cetacean Res Manag 10: 179-182

Avila IC, Kaschner K, Dormann CF (2018) Current global risks to marine mammals: taking stock of the threats. Biol Conserv 221:44-58

* Brehmer P, Josse E, Nøttestad L (2012) Evidence that whales (Balaenoptera borealis) visit drifting fish aggregating devices. Mar Ecol 3:176-182

Castro C, Rosero, P (2010) Interacción de cetáceos menores con artes de pesca artesanal en el Parque Nacional Machalilla-Ecuador. Esfuerzos para mitigar el impacto de actividades pesqueras en cetáceos en los países del Pacífico Sudeste. In: CPPS Plan de acción para la protección del medio marino y áreas costeras del Pacífico Sudeste. Comisión Permanente del Pacífico Sur, Guayaquil (in Spanish)

Castro C, Van Waerebeek K (2019) Strandings and mortality of cetaceans due to interactions with fishing nets in Ecuador, 2001-2017. Document SC/68A/HIM/17 presented to the International Whaling Commission Scientific Committee, 10-22 May 2019. IWC

* Castro J, Santiago J, Santana-Ortega A (2002) A general theory of fish aggregation to floating objects: an alternative to the meeting point hypothesis. Rev Fish Biol Fish 11:255-277

Castro C, Groch K, Marcondes M, Van Bressem M, Van Waerebeek K (2008) Miscellaneous skin lesions of unknown aetiology in humpback whales (Megaptera novaeangliae) from South America. Document SC/60/DW18 presented to the International Whaling Commission Scientific Committee, 23-27 June 2008. IWC

Castro C, Denkinger J, Haase B, Utreras V, Alava JJ, Tirira DG, Amador LA (2011a) Short-finned pilot whale (Globicephala macrorhynchus). In: Tirira DG (ed) The red book of Ecuadorian mammals, 2nd edn. Fundación Mamíferos y Conservación, Pontificia Universidad Católica del Ecuador y Ministerio del Ambiente del Ecuador, Quito, p 276 (in Spanish)

Castro C, Alava JJ, Denkinger J, Haase B and others (2011b) Humpback whale (Megaptera novaeangliae). In: Tirira DG (ed) The red book of Ecuadorian mammals, 2nd edn. Fundación Mamíferos y Conservación, Pontificia Universidad Católica del Ecuador y Ministerio del Ambiente del Ecuador, Quito, p 232-234 (in Spanish) 
Castro C, Cárdenas D, Kaufman G, Van Waerebeek KV (2018) Marine mammals used as bait with improvised Fish Aggregating Devices in Ecuador. Document SC/ $67 \mathrm{~B} / \mathrm{SM} / 06$ presented to the International Whaling Commission Scientific Committee, 24 April-6 May 2018, Bled. IWC

* Dagorn L, Holland KN, Restrepo V, Moreno G (2013) Is it good or bad to fish with FADs? What are the real impacts of the use of drifting FADs on pelagic marine ecosystems? Fish Fish 14:391-415

Dempster T, Taquet M (2004) Fish aggregation device (FAD) research: gaps in current knowledge and future directions for ecological studies. Rev Fish Biol Fish 14:21-42

El Diario (2009) Animales marinos fueron encontrados muertos en Cojimíes. 9 November 2009. www.eldiario. ec/noticias-manabi-ecuador/135848-animales-marinosfueron-encontrados-muertos-en-cojimies/

Félix F, Samaniego J (1994) Incidental catches of small cetaceans in the artisanal fisheries of Ecuador. Rep Int Whaling Comm Spec Is 15:475-480

Félix F, Van Waerebeek K (2005) Whale mortality from ship strikes in Ecuador and West Africa. Lat Am J Aquat Mamm 4:55-60 (LAJAM)

Félix F, Haase B, Davis JW, Chiluiza D, Amador P (1997) A note on recent strandings and bycatches of sperm whales (Physeter macrocephalus) and humpback whales (Megaptera novaeangliae) in Ecuador. Rep Int Whaling Comm 47:917-919

Filmalter JD, Capello M, Deneubourg JL, Cowley PD, Dagorn L (2013) Looking behind the curtain: quantifying massive shark mortality in fish aggregating devices. Front Ecol Environ 11:291-296

Fonteneau A, Chassot E, Bodin N (2013) Global spatio-temporal patterns in tropical tuna purse seine fisheries on drifting fish aggregating devices (DFADs): taking a historical perspective to inform current challenges. Aquat Living Resour 26:37-48

Geraci JR, Lounsbury VJ (2005) Marine mammals ashore: a field guide for strandings, 2nd edn. National Aquarium in Baltimore, Baltimore, MD

Gershman D, Nickson A, O'Toole M (2015) Estimating the use of FADs around the world: an updated analysis of the number of fish aggregating devices deployed in the ocean. Pew Charitable Trusts, Washington, DC

Gilman E (2015) Status of international monitoring and management of abandoned, lost and discarded fishing gear and ghost fishing. Mar Policy 60:225-239

Gilman E, Chopin F, Suuronen P, Kuemlangan B (2016) Abandoned, lost and discarded gillnets and trammel nets. Methods to estimate ghost fishing mortality, and status of regional monitoring and management. Tech Pap No. 600. FAO, Rome

Gilman E, Bigler B, Muller B, Moreno G and others (2018) Stakeholders' views on methods to identify the ownership and track the position of drifting fish aggregating devices used by tuna purse seine fisheries with reference to the FAO Draft Guidelines on the Marking of Fishing Gear. Tech Pap No. T631. FAO, Rome

Haase B, Félix F (1994) A note on the incidental mortality of sperm whales (Physeter macrocephalus) in Ecuador. Rep Int Whal Comm Spec Issue 15:481-483

Hall M, Roman M (2013) Bycatch and non-tuna catch in the tropical tuna purse seine fisheries of the world. FAO Fisheries and Aquaculture Technical Paper No. 568. FAO, Rome
Herrera M, Mendivez W, Solis-Coello P (1999) Observaciones sobre la alta mortalidad de tortugas marinas registradas en las costas de las provincias del Guayas y Manabí. Resumen Ejecutivo, Septiembre de 1999. Instituto Nacional de Pesca, Guayaquil

Hucke-Gaete R, Crespo E, Schlatter R (eds) (2004) Aquatic mammals in Latin America: proceedings of a workshop on identifying high-priority conservation needs and actions. UNEP/CMS Secretariat, Bonn

IUCN (2019) The IUCN Red List of Threatened Species. Version 2019-2. www.iucnredlist.org (accessed 29 October 2019)

Jiménez PJ, Alava JJ (2014) Population ecology and anthropogenic stressors of the coastal bottlenose dolphin (Tursiops truncatus) in the El Morro Mangrove and Wildlife Refuge, Guayaquil Gulf, Ecuador: toward conservation and management actions. In: Samuels JB (ed) Dolphins: ecology, behavior and conservation strategies. Nova Science Publishers, Hauppauge, NY, p 129-163

Jiménez PJ, Alava JJ, Castro C, Samaniego J, Fair, P (2018) Stranding of small cetaceans with missing fins raises concerns on cetacean conservation in Ecuador: bycatch or targeted fisheries? Int J Fisheries Sci Res 2:1006

Mangel JC, Alfaro-Shigueto J, Van Waerebeek K, Cáceres $\mathrm{C}$ and others (2010) Small cetacean captures in Peruvian artisanal fisheries: high despite protective legislation. Biol Conserv 143:136-143

Martínez-Ortiz J, Aires-da-Silva AM, Lennert-Cody CE, Maunder MN (2015) The Ecuadorian artisanal fishery for large pelagics: species composition and spatio-temporal dynamics. PLOS ONE 10:e0135136

Moreno G, Dagorn L, Capello M, Lopez J, and others (2016a) Fish aggregating devices (FADs) as scientific platforms. Fish Res 178:122-129

Moreno G, Restrepo V, Dagorn L, Hall M and others (2016b) Workshop on the use of biodegradable fish aggregating devices (FAD). ISSF Technical Report 2016-18A. International Seafood Sustainability Foundation, Washington, DC

Morgan AC (2011a) Fish aggregating devices and tuna: impacts and management options. Ocean Science Division, Pew Environment Group, Washington, DC

Morgan AC (2011b) Dispositivos agregadores de peces (plantados) y atún: Impactos y opciones de ordenación. Ocean Science Division, Pew Environmental Group, Washington, DC

Murua J, Itano D, Hall M, Dagorn L and others (2016) Advances in the use of entanglement- reducing drifting fish aggregating devices (dFADs) in tuna purse seine fleets. ISSF Technical Report 2016-08. International Seafood Sustainability Foundation, Washington, DC

NMFS (National Marine Fisheries Service) (2016) Fish and fish product import provisions of the Marine Mammal Protection Act; Final Rule. Federal Register 81 FR 54389, Document \# 2016-19158; 81:54389-54419. National Oceanic and Atmospheric Administration, Washington, DC

Northridge SP (1985) Estudio mundial de las interacciones entre mamíferos marinos y la pesca. Documento Técnico de Pesca 251. FAO, Rome

Reeves R, Smith BD, Crespo E, di Sciara N (compilers) (2003) Whales, dolphins and porpoises: 2002-2010 Conservation Action Plan for the world's cetaceans. Cetacean Specialist Group. IUCN, Gland

Scheidat M, Castro C, Gonzalez J, Willians R (2004) Behavioural responses of humpback whales (Megaptera novae- 
angliae) to whalewatching boats near Isla de la Plata, Machalilla National Park, Ecuador. J Cetacean Res Manag 6:63-68

Tirira DG (2011) Libro Rojo de los mamíferos del Ecuador, 2nd edn. Publicación Especial 8. Fundación Mamíferos y Conservación, Pontificia Universidad Católica del Ecuador y Ministerio del Ambiente del Ecuador, Quito

Tunacons (2019) Ecuador's Tunacons launches biodegradable FAD contest. www.undercurrentnews.com/2018/ 10/15/ecuadors-tunacons-launches-biodegradable-fadcontest/ (accessed 2 March 2020)

Van Bressem MF, Simões-Lopes PC, Félix F, Kiszka J and others (2015) Epidemiology of lobomycosis-like disease in bottlenose dolphins Tursiops spp. from South America and southern Africa. Dis Aquat Org 117:59-75

Editorial responsibility: Bryan P. Wallace, Fort Collins, CO, USA
Van Waerebeek K, Reyes JC (1994) Post-ban small cetacean takes off Peru: a review. Rep Int Whaling Comm Spec Issue 15:503-520

*Van Waerebeek K, Van Bressem MF, Félix F, AlfaroShigueto J and others (1997) Mortality of dolphins and porpoises in coastal fisheries off Peru and southern Ecuador in 1994. Biol Conserv 81:43-49

*Van Waerebeek K, Alfaro-Shigueto J, Montes D, Onton K and others (2002) Fisheries related mortality of small cetaceans in neritic waters of Peru in 1999-2001. Paper SC/54/SM10 submitted to the IWC Scientific Committee, April 2002, Shimonoseki. IWC

Van Waerebeek K, Baker A, Félix F, Gedamke J and others (2007) Vessel collisions with small cetaceans worldwide and with large whales in the Southern Hemisphere, an initial assessment. Lat Am J Aquat Mamm 6:43-69

Submitted: September 3, 2019; Accepted: November 25, 2019 Proofs received from author(s): March 3, 2020 